\title{
A GENERAL ANALYSIS OF EXCLUSIONARY CONDUCT AND REFUSAL TO DEAL - WHY ASPEN AND KODAK ARE MISGUIDED
}

\author{
Dennis W. Carlton \\ Working Paper 8105 \\ http://www.nber.org/papers/w8105
NATIONAL BUREAU OF ECONOMIC RESEARCH
1050 Massachusetts Avenue
Cambridge, MA 02138
February 2001

I thank Jonathan Baker, Robert Gertner, William Lynk, Gregory Pelnar, Sam Peltzman, J. Robert Robertson, Steven Shapiro, Michael Waldman and Michael Whinston for helpful discussions. The views expressed herein are those of the author and not necessarily those of the National Bureau of Economic Research.

(C) 2001 by Dennis W. Carlton. All rights reserved. Short sections of text, not to exceed two paragraphs, may be quoted without explicit permission provided that full credit, including $\odot$ notice, is given to the source. 
A General Analysis of Exclusionary Conduct and Refusal to Deal Why Aspen and Kodak are Misguided

Dennis W. Carlton

NBER Working Paper No. 8105

February 2001

JEL No. L

\begin{abstract}
This paper analyzes the question: When should a single firm have a duty to deal with another? The paper uses a series of economic models to answer the question, assuming the goal is to prevent harm to competition, and applies the economic analysis to the leading cases to show when antitrust enforcement is appropriate and when it is not. The analysis shows that, to prevent harm to competition, the role for antitrust should be quite limited and that two leading cases, Aspen and Kodak, represent a dangerous direction for antitrust policy.
\end{abstract}

\author{
Dennis W. Carlton \\ Graduate School of Business \\ University of Chicago \\ 1101 East 58th Street \\ Chicago, IL 60637 \\ and NBER
}




\section{INTRODUCTION}

Twice in the past fifteen years, the Supreme Court has suggested that a single firm might, under some circumstances, have a duty to deal with another firm. In Aspen $^{1}$, the Court upheld a jury verdict finding an antitrust violation when a firm that controlled three of the four downhill skiing mountains in Aspen terminated a collaboration on an all-Aspen skiing pass with the fourth mountain. In Kodak $^{2}$, the Court denied summary judgment for the defendant when Kodak took steps to make it more difficult for independent service organizations (ISOs) to service Kodak photocopiers, in part by denying the ISOs access to replacement parts they had previously been able to purchase from Kodak or its authorized parts manufacturers. Both cases suffer from confused economic reasoning. To the extent these cases have expanded the duty that a single firm may have to deal with others, they represent a dangerous direction for antitrust.

This paper analyzes the question: When should a single firm have a duty to deal with another? It uses an economic analysis to answer the question, assuming the goal is to prevent harm to competition, and applies that analysis to the leading cases to show when antitrust enforcement is appropriate and when it is not. The antitrust doctrine of a duty to deal automatically creates a tension because the antitrust laws are premised on the simple notion that rivalry among firms benefits consumers, yet a doctrine of a duty to deal clearly limits that rivalry. Indeed, the doctrine usually arises in discussions regarding exclusionary conduct which, as many commentators have noted, is difficult to distinguish from beneficial competition because they both result in an increase in sales of one firm at the expense of rivals. Overaggressive use of antitrust claims against exclusionary conduct therefore will inevitably reduce the incentive for beneficial competition.

\footnotetext{
${ }^{1}$ Aspen Skiing Co. v. Aspen Highlands Skiing Corp, 472 U.S. 585 (1985).
} 
Economists have grown more knowledgeable about how business strategies can benefit a firm and harm its rivals. Indeed, every major business school now has courses in strategic behavior. Economists have a much clearer understanding of how various modes of conduct that involve either explicit or implicit refusals to deal -- e.g., exclusive dealing, tie-in sales, closed joint ventures, product incompatibilities, discriminatory pricing, setting high prices -- can be used especially in industries with rapid change and scale economies to cement market power. This advance in economists' knowledge is all to the good, but it should not necessarily translate into more active antitrust policy. The zeal with which economists foist these theories on antitrust practitioners must not obscure two key facts. First, the harm to a rival is not a harm to competition. Empirically documenting a harm to competition from various exclusionary conduct is usually quite difficult and is not necessarily an implication of the theories. Economic theorizing about possible harm to competition has far outpaced empirical verification. In Section II of this paper, I explain what economists (or at least this economist) now know about how explicit or implicit refusals to deal harm competition. Second, economists often neglect to focus on where antitrust enforcement is likely to help or harm the economy the most. Yet, economists have learned quite a bit about the sources of economic growth and transaction costs. I discuss in Section III some policy issues related to antitrust enforcement in light of the current knowledge about R\&D and transaction costs.

Although it is understandable why some could take the position that the evidence to date on refusals to deal is so ambiguous that there should be no antitrust restrictions, I do not take such an extreme view. I start from the premise that there can be a legitimate role for antitrust restrictions on refusals to deal. Sections II and III develop an economic framework that Section IV uses to analyze selected refusal to deal cases. The analysis shows that, to prevent harm to competition, the role for antitrust should be quite limited. In particular, I will argue that the two

\footnotetext{
(...continued)

${ }^{2}$ Eastman Kodak Co. v. Image Technical Service Inc. 504 U.S. 451 (1992).
} 
leading cases, Aspen and Kodak, that are frequently cited by plaintiffs seeking to force a rival to deal with them, represent a dangerous direction for antitrust. Only a narrow construction of those cases will prevent harm to competition.

At the outset, let me be clear on what the paper will not address. The paper will not address the duty to deal that a joint venture of rivals has. That is an interesting and complicated question that I have dealt with elsewhere. ${ }^{3}$ It raises different issues than those raised by the duty to deal that a single firm should have. The reason is that, in general, the antitrust laws treat collective action differently (more harshly) than unilateral action, implicitly adopting the view that collective action is more likely to create a competitive harm than is the action of a single firm. The paper also will not deal with a firm that is subject to regulation. Such a firm can use refusals to deal in order to evade regulation whose very presence suggests that there is already some market power that competition fails to constrain. ${ }^{4}$

\section{REFUSALS TO DEAL -- ECONOMIC ANALYSIS}

There has been an increased economic understanding of the circumstances in which a

\footnotetext{
${ }^{3}$ See Dennis W. Carlton and Alan S. Frankel, "The Antitrust Economics of Credit Card Networks," Antitrust Law Journal, vol. 63 (1995a); Dennis W. Carlton and Alan S. Frankel, "The Antitrust Economics of Credit Card Networks: Reply to Evans and Schmalensee Comment," Antitrust Law Journal, vol. 63 (1995b); Dennis W. Carlton and Alan S. Frankel, "Antitrust and Payment Technologies," Review, Federal Reserve Bank of St. Louis (November/December 1995c); and Dennis W. Carlton and Steven Salop, "You Keep on Knocking But You Can't Come In: Evaluating Restrictions on Access to Input Joint Ventures," Harvard Journal of Law \& Technology, (Volume 9, Summer, 1996).

${ }^{4}$ The paper avoids any discussion of "essential facilities." That doctrine is a purely legal concept -- no economic concept of essentiality exists as distinct from market power in an analysis of competition. Because I don't find that the concept adds to the analysis of market power, it has only the power to confuse because it would appear to represent a separate concept which must therefore mean it creates new applications of the antitrust laws. See Phillip E. Areeda, "The Essential Facilities Doctrine: An Epithet In Need of Limiting Principles," Antitrust Law Journal, 58, 841-53 (1990) for a critical assessment of the essential facilities doctrine. Some have claimed that the essential facility doctrine allows the antitrust laws to efficiently control natural monopolies. That claim seems dubious especially when detailed knowledge of an industry is needed to design efficient regulation. A judge or jury is not a substitute for a regulatory agency.
} 
firm would refuse to deal with another firm. ${ }^{5}$ I will deal with several distinct cases depending on whether the relation between the firms is horizontal or vertical -- a distinction sometimes lost in cases. I will also distinguish static from dynamic models. Dynamic models are especially important in analyzing industries (e.g., computer industry) rapidly evolving over time where there are dependencies over time. I will also describe how a refusal to deal can be effectively implemented by various price incentives, tie-ins, and incompatible product designs.

In the following discussion, product $A$ will be the primary product over which Firm 1 has market power. There will sometimes be a complementary product B that Firm 1 can produce. Depending on the particular case, other firms may be able to produce A or B or both. Let us now look at how a refusal to deal by Firm 1 can affect competition in various cases.

Case 1: $\quad$ Firm 1 and Firm 2 are rivals in producing A. They form (or contemplate forming) a joint venture in order to produce or market $A$ more efficiently. Firm 1 refuses to continue its participation in (or to join) the joint venture.

In Case 1, which as we will soon see Aspen fits into, the firms are rivals and their collective action raises the usual issues about the suppression of competition. The joint venture is limited to those activities necessary to achieve efficiency. So, for example, if the production joint venture is formed for efficiency reasons, it is not necessary for the pricing to be collectively determined. Instead, the members of the joint venture could buy output at marginal cost and then set prices independently. ${ }^{6}$ The refusal to deal issue arises only insofar as one firm refuses to continue its participation in (or to join) the venture. But the decision of a firm to participate must depend on that firm's assessment of its gain from participating. If it is indeed efficient for the joint venture to exist, there will be some payments between the firms that will induce

\footnotetext{
${ }^{5}$ See, e.g., J. Ordover, G. Saloner and S. Salop, "Equilibrium Vertical Foreclosure," American Economic Review 80:127-141 (1990); Michael Whinston, "Tying, Foreclosure and Exclusion," American Economic Review 80:837-859 (1990); Eric Rasmussen, "Naked Exclusion," American Economic Review 81:1137-1145 (1991); B. Douglas Bernheim and Michael Whinston, "Exclusive Dealing," Journal of Political Economy, (1999); and Dennis W. Carlton and Michael Waldman, "The Strategic Use of Tying to Preserve and Create Market Power in Evolving Industries," Working Paper No. 145, George J. Stigler Center for the Study of the Economy and the State, University of Chicago (1998), revised March, 2000.
} 
participation. If such payments don't occur, it is hard to see a justification for the courts to force participation in the joint venture since one of the parties will be made worse off by the participation. ${ }^{7}$ Using the courts to improve the bargaining position of one party relative to another when no antitrust issue exists to justify intervention creates perverse incentives in which one party may prefer to rely on the courts to create (or perpetuate) the joint venture, and may hope thereby to gain a financial advantage by relying on the court's reckoning of a "fair" division of profits rather than on the rigors of marketplace economics.

Since any forced participation would necessarily have to set the price terms, the courts become a type of regulatory body setting complex terms of trade and enforcing cooperation in an area where, unlike a regulatory body, the courts have no special expertise and where, if it were efficient to do so, the two firms have a private incentive to cooperate. In such a case, the only outcome to expect from court intervention is inefficiency.

Case 2: $\quad$ Firm 1 and Firm 2 both produce and compete in product A (or variants of product A). Firm 1 is the dominant firm. Firm 1 refuses to deal with any customer or intermediary (e.g., wholesaler, retailer) that also deals with Firm $2 .^{8}$

Case 2 is the classic case of exclusive dealing, as exemplified by e.g., Standard Fashion. ${ }^{9}$. It is well known that exclusive dealing can be procompetitive and create incentives for Firm 1 to, for example, provide customer lists, promotional help and training for its distributors $^{10}$. Without the exclusivity, Firm 2 could use the same distributors to free ride on Firm 1's efforts, depriving Firm 1 of the full incentive to engage in such activity. However, it is also

(...continued)

${ }^{6}$ For an antitrust analysis of joint ventures, see Carlton and Salop, supra at 3.

${ }^{7}$ If agency or moral hazard problems prevent such payments from being implemented, the joint venture will not occur. However, in this case, it is completely unclear why a court can create a contractual structure that the parties cannot. The solution is a different organizational form, not a court administered joint venture.

${ }^{8}$ This is the case that Rasmussen (1991), supra at 5, focuses on. He shows that, even if customers correctly perceive that exclusivity will harm them, they will, through competition with each other, be forced to accept exclusivity and Firm 1 will keep the resulting profits from the market power it creates. See also Bernheim and Whinston, op. cit.

${ }^{9}$ Standard Fashion Co. v. Margrane-Houston Co., 258 U.S. 346 (1922).

${ }^{10}$ See, e.g., Dennis W. Carlton and Jeffrey Perloff, Modern Industrial Organization, Scott, Foresman \& 
known that, in the presence of scale economies, exclusive dealing can be a way of depriving Firm 2 (or its distributors) of the necessary scale to achieve efficiencies, even though, absent the exclusivity, Firm 1 and Firm 2 would both be large enough to achieve efficiency.

In antitrust cases involving exclusivity, the courts "weigh" the harm to competition against any benefits to judge whether the exclusivity helps or harms consumers. Although that solution is easy to state, I am generally unaware of attempts to quantitatively weigh both costs and benefits. Instead, courts typically follow the path of deciding whether scale economies are relevant so that the claim of exclusion is material and, if so, then figure out whether the facts allow the case to be placed in the category "no free riding, significant scale" or "free riding, no significant scale." I'm skeptical of the ability of courts to decide cases in the category "significant free riding, significant scale economies," though conceptually economists could produce quantitative evidence to aid courts to weigh the two effects.

Although it may sound like exclusive dealing cases are relatively straightforward for courts to identify and deal with, that is not the case once one realizes that exclusive dealing can be achieved in ways other than explicit prohibition by contract. For example, suppose Firm 1's product is dominant, and that economies of scale preclude having more than one distributor per city. Firm 1, instead of using explicit exclusive dealing, sets a fixed charge to each distributor (perhaps based on the distributor's total possible sales of all brands) and a zero marginal charge. Given that, by assumption, each distributor carries Firm 1's product, each distributor will have a reduced incentive to carry Firm 2's product because the decision to carry Firm 2's product is compared not against the average cost of carrying Firm 1's product but against the marginal cost (i.e. 0) of carrying additional units of Firm 1's product. Without any contractual exclusivity, distributors, in their own self interest, could respond to the non-linear pricing (pricing that deviates from charging a constant price per unit) offered by Firm 1 and become exclusive to

(...continued)

Co., third edition (1999), Ch 12. 
Firm 1. ${ }^{11}$ Thus, non-linear pricing (or other contractual terms) -- less extreme in appearance than outright contractual exclusive dealing -- can achieve the same ends as exclusive dealing. ${ }^{12}$

One approach to dealing with conduct such as non-linear pricing (or other contractual terms) that achieves exclusivity is simple to state: treat conduct that achieves the same exclusivity as would contractual exclusivity as a potential antitrust issue. Although this may seem sensible, if the goal is to prevent harm to competition, I caution that it may not be and that, if such an approach is followed, it should be used rarely and apply only to extreme pricing conditions (such as the previous example where the marginal price was zero) where marginal pricing below marginal cost is unambiguous. One reason that it may not be sensible is that volume discounts are ubiquitous in commerce as are special deals for big buyers. Such nonlinear pricing can reflect real economic savings that are difficult to measure (lower inventory costs, promotional or production costs) or simply may be ways that firms choose to compete for the most desirable customers. Attacking such common competitive behavior would likely create much turmoil and chill competition.

One may be inclined to evaluate non-linear pricing (e.g., price discounts) along traditional grounds that govern price predation cases. That is, if the incremental price of the last unit to the consumer is below marginal costs, the pricing is subject to further inquiry. But, three problems plague that analysis. First, in this static model, predation makes no sense so analogies based on it are tenuous. Second, it is well known that calculating marginal costs from accounting data is difficult so it may not be so easy to determine if the incremental price exceeds marginal costs. Third, and perhaps most important, the analyst may not observe a price schedule as a function of volume and may have to infer it from observations of price

\footnotetext{
${ }^{11}$ The 1995 Department of Justice case against Microsoft was closed based on a consent decree forbidding Microsoft from using such contracts. (cite)

${ }^{12}$ See Willard Thom, David Balto and Neil Averitt, "Anticompetitive Aspects of Market-Share Discounts and Other Incentives to Exclusive Dealing," 67 Antitrust Law Journal 615 (2000) for an analysis of how various contractual terms on pricing and penalty clauses can adversely affect competition by creating partial exclusivity. See also Ronald Davis, "Pricing With Strings Attached -- At Sea in
} 
across buyers of different sizes. But it is well known that in models that deviate from perfect competition big buyers can obtain a much lower price than small buyers. So, for example, a buyer of 1 unit may pay $\$ 10$, while a buyer of 2 units may pay only $\$ 5$ per unit. Suppose that marginal cost is $\$ 4$ and that a "big buyer" can vertically integrate for a sunk cost of $\$ 2$. The price to the large buyer is clearly above marginal cost, yet the implied incremental price that the analyst calculates from price data across buyers is $0 . \quad$ ( $\$ 10$ for 1 unit, $\$ 10$ paid in total for 2 units). Attempts to infer antitrust liability based on quantity discounts inferred from prices across buyers of different sizes could lead to the peculiar result of inhibiting competition for the large buyers. ${ }^{13}$ The consequence would be much like the Robinson Patman Act, to chill price competition by imposing price uniformity across customers. If antitrust does pursue contracts that create de facto exclusivity, it would be wise to limit attention to those contracts with extreme pricing terms like those of the Microsoft-type where it is unambiguous that incremental price is below marginal cost for many buyers. ${ }^{14}$ Exclusivity achieved through non-pricing terms (e.g., contractual provisions affecting dealings with other parties) should also be treated cautiously under a rule of reason since often such provisions can generate efficiencies. ${ }^{15}$

(...continued)

Concord Boat and LePage's," Antitrust Summer 2000, 69.

${ }^{13}$ Notice that non-linear pricing (unrelated to cost savings) can only occur if buyers do not engage in arbitrage. In such a case, the example shows why it is improper to infer incremental price from an analysis of price across buyers. If arbitrage is possible, then there will be no detectable differences in incremental price as a function of volume (after adjusting for cost differences).

${ }^{14}$ In Concord Boat Corp. et al v. Brunswick, 2000 U.S. App. Lexis 4673, the court showed a great reluctance to equate non-linear pricing with exclusivity. In Barry Wright Corp. v. ITT Grinnell Corp. et al 724 F. 2d 227 (First Cir. 1983), the court ruled that discounts were allowable as long as the discounted price exceeded both average and marginal cost. The court did not use incremental price (implied by comparing the extra charge for the incremental volume) and eloquently describes the difficulties of condemning behavior that is generally procompetitive. As a general theoretical matter, it may be possible to conceive of models where above-cost pricing is anticompetitive, but identifying such cases may be hard. The Brooke Group Ltd. v. Brown \& Williamson Tobacco Corp., 509 US 209 (1993) (identifying anticompetitive above-cost pricing is "beyond the practical ability of a judicial tribunal ... without courting intolerable risks of chilling legitimate price cutting," 223).

${ }^{15}$ Exclusivity is of course not the key issue. It is that the cost of obtaining efficient distribution or other inputs is raised for a rival, thus impairing the competitive effectiveness of the rival with a resulting harm to competition. 
Case 3a: $\quad$ Firm 1 is a monopolist of product $A$, and also competes with Firm 2 in the sale of product $B$. Product $A$ is an input (or an important complement) to product $B$ for all consumers. Firm 1 refuses to deal with (e.g., sell $A$ to) Firm 2.

This case (which, as explained in Section IV, Kodak belongs to) has the striking feature that though Firm 1 and Firm 2 appear to compete, the rivalry is illusionary. The reason is the assumed monopoly power of Firm 1 in product A. That power presumably allows it to set the price for A at any level or to use any contractual mechanism it wants to sell A including nonlinear pricing. ( $\mathrm{l}$ am assuming the monopolist can engage in price discrimination absent the tie. I discuss below the case where the tie creates the ability to [better] price discriminate.) Firm 2 is already at the mercy of Firm 1. Firm 1 therefore gains nothing by the elimination of Firm 2 in the competition for B! This is because it can already extract all the profits of Firm 2 through pricing of $A$. If Firm 2 happens to be more efficient than Firm 1 in the production of product $B$, then Firm 1 has an incentive to induce Firm 2 to be the sole supplier of product 2, but not to allow Firm 2 to price product B at a monopoly level (to avoid the usual double marginalization problem), and Firm 2 will have an incentive to accept such an offer. The key insight is that a refusal to deal by Firm 1 raises no antitrust issue since there is no additional market power for Firm 1 to achieve by elimination of an equally efficient rival in product $B{ }^{16}$

Now consider the case in which the tie allows the firm to practice price discrimination that would not otherwise be possible. Suppose product B is distribution services for product $A$, and suppose that there are two groups of customers. Firm 2 sells to one set of customers and Firm 1, the manufacturer of product A, sells to another. This type of circumstance often arises when a manufacturer sells direct to some customers but relies on distributors to sell to other customers. Suppose further that the prices to the two sets of customers are different, so that

\footnotetext{
${ }^{16}$ This point has nothing to do with whether $A$ and $B$ are used in fixed proportions. It only has to do with the assumed ability of a monopolist of $A$ to price $A$ as he sees fit (perhaps using non-uniform pricing). In such a setting, Firm 1's production of B guarantees that Firm 2 can earn only a competitive return. This point is related to the so-called "Chicago" approach, see, e.g., Richard Posner and Frank Easterbrook (1982), Antitrust, West Publishing Co., 2nd ed., p. 802.
} 
Firm 1 is essentially using Firm 2 to engage in price discrimination with the price to the customers of Firm 1 higher than of Firm 2's customers. There are no unambiguous negative consequences of price discrimination and, as I understand the antitrust laws, Firm 1's actions are perfectly lawful. ${ }^{17}$ Suppose however that Firm 2 discovers the pricing discrepancy (or conditions change) so that Firm 2 begins to engage in arbitrage by selling to Firm 1's customers and thereby prevents Firm 1 from engaging in price discrimination. Firm 1 responds by refusing to supply Firm 2 and performing all distribution itself, thereby allowing it to restore the previous pricing arrangement. Should this refusal to deal be deemed a violation of the antitrust laws, assuming the goal is to prevent harm to competition? No, for at least two reasons.

First, it is well known that the theoretical effects of price discrimination on social welfare are ambiguous. The ability to practice some price discrimination does not necessarily or generally lower social welfare -- indeed, we know that perfect price discrimination leads to efficient outcomes. Second, if price discrimination were to create antitrust liability, then it should do so even if Firm 2 did not exist and only Firm 1 distributed the product. But, as l've explained earlier, different prices to different consumers are a ubiquitous fact of our economy and it is not feasible (nor, in light of its welfare properties, desirable) to ban it. To recognize how widespread price discrimination is, just think of all the coupons and rebates one gets daily in the mail, newspaper, or just walking down the aisle of any large store. It's hard to imagine taking the position that those discounts violate the antitrust law. But, then, that same logic must also apply to Firm 1 in its dealings with Firm 2 in this Case $3 a$.

Case 3b: $\quad$ Same as Case $3 a$ but now products $A$ and $B$ are not complements for some consumers, and there are scale economies in the production of $\mathrm{B}$.

The new feature of Case $3 b$ compared to Case $3 a$ is that Firm 2 can compete against Firm 1 and have an independent effect on competition for those subset of customers who don't

\footnotetext{
${ }^{17}$ To avoid Robinson-Patman issues, assume that consumers are final consumers who personally consume the product.
} 
desire Firm 1's product A. If Firm 2 enjoyed constant returns to scale, then Firm 2 would be completely insulated from actions of Firm 1. But in the presence of scale (or scope) economies, it is possible that Firm 1 can impair Firm 2's ability to compete. This insight is primarily due to Whinston. ${ }^{18}$

To see how a refusal to deal could harm competition, imagine initially how prices would be set. Firm 1 would want to make sure that Firm 2 did not earn rents on sales to customers who desire Firm 1's products -- much as in Case 3a. Suppose Firm 1 refuses to sell product A to any customer who consumes product B from Firm 2. This causes Firm 2's scale to drop below an economically efficient scale, and Firm 2 leaves the market for product B. This means that customers that want only product B now face a monopolist (Firm 1) and they suffer a harm from the reduced competition. To fix ideas, imagine a monopoly resort hotel on an island where hotel workers live. ${ }^{19}$ By requiring that hotel guests eat only in the hotel, the hotel may prevent other restaurants from developing that would otherwise serve both tourists and natives. Although the tourists were already subject to the monopoly power of the hotel (through the room rate), natives were not and hence are harmed by the reduction in competition. Note the special features required for a harm to competition -- scale economies combined with a group of consumers that desire only product B.

As before, this exclusivity can be achieved through contractual means other than explicit exclusive dealing. The simplest way would be for the hotel to bundle the restaurant with the room so that once on the island, the marginal cost to a tourist of a hotel meal is zero. In another setting, the tie-in could be achieved through product design bundling achieved either through explicit contract (as in the hotel restaurant example) or through the introduction of product design incompatibilities (so that those who buy $A$ and want to use $B$ with it must buy $B$ from Firm 1 , otherwise product $B$ is useless.)

\footnotetext{
${ }^{18}$ Michael Whinston, supra at 5.
} 


\section{Case 4 - Dynamic Models With Competition in Products A and B:}

The final class of models I discuss are dynamic ones with the possibility of competition in all products. It is the introduction of competition in both products $A$ and $B$ that leads to understanding some of the motives for certain exclusionary conduct that Case 3 misses, and it is the dynamic nature of the models that leads to realistic applications and new insights into behavior in the IBM and Microsoft cases. ${ }^{20}$ Many industries that have been attacked on antitrust grounds are rapidly changing and have dynamic interdependencies that create interesting incentives not present in a static model for refusals to deal. The key insight of this class of models is that actions today that keep Firm 2 small can benefit Firm 1 later. The well studied models of price predation emerge as one possible strategy in these dynamic models. Perhaps more relevant, in light of the relative absence of empirical evidence of predation as a successful strategy, is the observation that, in a dynamic model, the cost of being small initially can be magnified in later periods especially with assumptions about network dependencies, importance of installed base, or scale economies. In those settings, strategic behavior designed to keep a rival small initially can yield later significant competitive advantage. It is these dynamic cases into which the Microsoft and IBM cases fit.

Consider first the dynamic version of the previous Case 3a. Suppose that initially Firm 1 is a monopolist of $\mathrm{A}$ and also produces a complementary product B. Firm 2 can also produce a version of product B which has some superior properties (e.g., better quality, lower production cost) to the version of product B produced by Firm 1. It would seem, and indeed it is so, that Firm 1 would be delighted to rely on Firm 2 to produce its superior product B, because that will make product A more valuable. In such circumstances, Firm 1 would not try to destroy Firm 2

\footnotetext{
(...continued)

${ }_{19}$ I thank R. Gertner for this example.

${ }^{20}$ See, e.g., U.S. v. IBM, Docket No. 69-CIV 2000 (S.D.N.Y. 1969) and U.S. v. Microsoft, 87 F. Supp. 2d 30, (D.D.C. 2000). See Carlton and Waldman (2000), supra at 5, for a detailed discussion of strategic behavior involving tie-in sales in dynamic models.
} 
or restrict Firm 2's size. This is exactly the analogous result to Case 3a above. The same results continue to hold in a dynamic version of the model with intertemporal linkages caused either by scale/scope effects or network effects. By scale/scope effects, I mean that the average cost of producing aggregate output over time falls with output (e.g., total cost $=\$ 100+$ output in period $1+$ output in period 2 ). By network effects, I mean that the desirability to a consumer of a particular version of product B depends on how many other consumers use that version. For example, if product $B$ is word processing software, a consumer prefers the situation where other people use the exact same word processing program rather than another word processing program because it makes it easier to share files or transmit documents to others.

Now let us change the model and introduce the possibility of competition for product $A$ in future periods and introduce either scale economies or network effects for product $\mathrm{B}$. Call this Case 4. The key insight is that Firm 1 can use its head start as the initial monopolist of product A to harm future competitors in product A by depriving them of a source of the complementary product B. By refusing to buy product B from Firm 2, Firm 1 can keep Firm 2 at an inefficiently small scale, and Firm 1 can thereby prevent a competitor in A from effectively competing against it in the future. (Remember that if future competition to Firm 1 in product A did not exist, we would be in a dynamic version of Case $3 a$ and there would be no reason for Firm 1 to want to harm Firm 2.) The ways that Firm 1 can refuse to deal with Firm 2 for product B are exactly the same as before -- e.g., exclusive dealing, tie-in sales of B to A, contractual provisions that provide incentives for de facto exclusivity, product design that makes Firm 2's product B incompatible with Firm A's product. All of these behaviors serve the same goal: to initially keep Firm 2 so small in its production of B that it is not an effective supplier of product B to competitors to Firm 1 in product $\mathrm{A}$ later on. ${ }^{21}$

${ }^{21}$ It is possible to construct a static version of Case 4 . In that static version, Firm 1 produces A and B, 
To give a concrete example, suppose that a monopolist of operating systems initially ties application programs to its system to prevent new applications programs from developing. In subsequent periods, entry of new operating systems would occur if there existed a stock of independent application programs. But, by assumption, such programs don't exist because Firm 1 prevented their development by foreclosing the initial market to them. For such models to have empirical relevance, the disadvantage that Firm 1 can impose on Firm 2 should be large relative to the time it takes Firm 2 to overcome the disadvantage. So, for example, if products change slowly, it will be harder for Firm 1 to harm Firm 2 because there will be a long period when competitors to Firm 1 exist (remember the initial monopoly of Firm 1 lasts only 1 period) and therefore a long time for Firm 2 to overcome any disadvantage in product B caused by an initial scale reduction.

The results of Case 4 are at once both novel and intuitive. It puts traditional antitrust policy on a much more solid footing than previous theories involving refusals to deal aimed at a complementary product. The only sensible theory (Whinston's theory) that could be used to attack exclusionary conduct aimed at product B was Case $3 \mathrm{~b}$ (the restaurant example) -- and that theory explains how the conduct creates market power in B (restaurants). In contrast, the theory in Case 4 explains how exclusionary conduct aimed at product B preserves market power in product $A$. It is a central insight that can explain why it is that some firms that are initially dominant will remain so even when the asymmetry that accounted for their initial dominance (e.g., patent, early entry) disappears only to be replaced by a new asymmetry

(...continued)

Firm 2 produces $B$ (with scale economies) and Firm 3 produces $A^{\prime}$, a variant of $A$. Firm 1 uses a refusal to deal with Firm 2 to keep it inefficiently small so as to prevent Firm 3 from having an efficient supply source thereby depriving consumers of $A^{\prime}$ and $B$. In this model, the refusal to deal does not accomplish much if many people demand $A^{\prime}$ (because then Firm 2 can achieve the necessary scale economies even if it makes sales only to consumers of $A^{\prime}$ ), while if few demand $A^{\prime}$, then the refusal to deal does not cause much harm to competition. The advantages of the dynamic model are that, as we will soon see, it applies readily to and is a more realistic description than the static model of some important industries. The model of Ordover et al (1990), supra at 5, presents a closely related static model, where the advantage to Firm 1 derives from its ability to force Firm 3 to face market power in 
caused by their strategic behavior that exploited time interdependencies. A firm with a head start stays ahead.

But the models of Case 4 have an even more striking implication. It can explain how Firm 1 can remain dominant even if product $A$ changes dramatically over time. It therefore explains how Firm 1 can transfer its monopoly over time from one product to another! It explains how firms like IBM or Microsoft can succeed in keeping their market power even as their products change enormously over time..$^{22}$ To see how this works, imagine that Firm 1 is the initial monopolist of product $A$. Product $B$, a complement to $A$, is available in the initial period from other firms as well as Firm 1. In period 2, another product, call it product C -- which could be product $A$, improved product $A$, or any other product that uses product B -- becomes available and producible by many firms. If Firm 1 can use refusals to deal in (i.e., to buy) product $B$ to prevent other firms from achieving the scale needed to produce product $B$, then Firm 1 can become the monopolist of this other product $C$ in period 2 as a result of it being the monopolist of $B$. The simple point is that Firm 1 can use refusals to deal to monopolize any future product $\mathrm{C}$ that uses product $\mathrm{B}$ as a complement. In this way, Firm 1 can transfer its initial monopoly power over time from product $A$ to product $C$. Again, the empirical relevance of this theory is likely to be greatest in rapidly changing industries with strong product complementarities and scale/scope effects and network effects. This theory provides a much more cogent explanation for refusals to deal than either traditional foreclosure theories that focus on the leveraging of power in A into B -- as in Case 3a, a theory that we have already explained has little basis, or Case 3b (whose empirical relevance at least based on existing tiein cases is not obvious).

(...continued) purchasing $B$, and the inability of Firms 2 and 3 to write an efficient contract.

${ }^{22}$ I discuss the Microsoft cases later. To see how aspects of the IBM cases would fit into Case 4, one must recognize that intelligence can reside in either the mainframe or in the peripheral, and therefore intelligence in peripherals can sometimes substitute for intelligence in the mainframe. 


\section{POLICY IMPLICATIONS}

Although the preceding theories enormously improve our understanding of the consequences of strategic behavior involving refusals to deals achieved either explicitly or implicitly, there remains the separate question of what use antitrust should make of these theories. One use is to recognize that the preceding theories that can generate a harm to competition need some sort of scale economies effect. Hence, any situation where such effects are absent are unlikely to be candidates for harmful exclusionary conduct.

The key issue is whether one can distinguish when these theories imply a harm to competition as distinct from a harm to a rival. It is possible to show that, in many of the above models, banning the exclusionary conduct can sometimes improve competition in the sense that consumers are better off. However, it is also important to recognize that, since these models have scale effects (or network effects), it is possible to show that the exclusionary conduct can

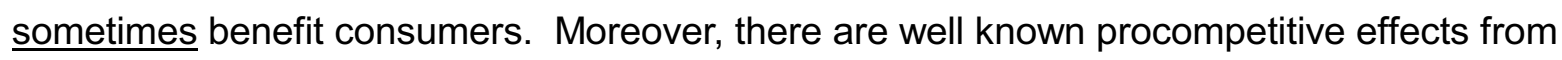
refusals to deal (in addition to scale effects). The most important ones include:

- $\quad$ exclusive dealing (either explicit or implicit) creates incentives for manufacturer training and promotion,

- product design (physical tie-ins) allows efficient product design,

- quantity discounts can encourage efficient order size, and

- refusals to deal can protect theft of intellectual property.

This means that any antitrust attack on an explicit or implicit refusal to deal must recognize this difficulty of identifying by theory alone a competitive harm, and instead must turn to a quantitative analysis which may be difficult to perform before condemning the practice in any specific case. I wish to highlight two efficiency defenses to which antitrust has on occasion paid special heed -- cost savings and innovation.

Every student of antitrust understands that increased market power creates an additional deadweight loss illustrated in Figure 1 as the trapezoidal area that represents the difference in deadweight loss between an initial situation (price at $P_{0}$ ) and one with some additional market power (price at $P_{1}$ ). A firm that can lower per-unit costs from $C_{0}$ to $C_{1}$ creates a benefit equal to 
the cross-hatched rectangle. The rectangle will have a bigger area than the trapezoid if the perunit cost saving is large, if the sales, $q_{s}$, are large, or if the change in output from the increased power is small. To preserve efficiencies in cases where they swamp deadweight loss, a good policy rule is: Be reluctant to interfere in situations where large efficiencies could be lost and especially where courts have difficulty measuring those efficiencies. It is very difficult for courts or economists to figure out whether transactions carried out within a firm could be efficiently carried out in the marketplace. For that reason, courts have been reluctant to intervene to order a vertically integrated firm to open some of its divisions to rivals. So, for example, a court is unlikely to order GM (even assuming it were a monopolist of cars) to supply production capability or marketing expertise to a new firm. ${ }^{23}$ Aside from the difficulty of setting the terms of trade, inefficiencies are likely to be created when activities done internally are required to be done externally. As Coase ${ }^{24}$ taught us years ago, a firm chooses to perform those functions that it can more efficiently perform internally than by reliance on the market. Hence, a rationale for antitrust's reluctance to intervene in activities within a firm is the recognition that such intervention could cause the loss of efficiencies like those of the rectangle.

Although the antitrust laws generally treat the boundary of a firm as inviolable, the same does not hold true about contractual arrangements between firms. A firm that uses a distributor, under an exclusive dealing arrangement, can be required to allow that distributor to sell other products. The underlying logic appears to be that the observation that two firms can contract with each other in the marketplace suggests that allowing an additional contract with another firm will cause either no harm or a harm that can be weighed against the competitive benefits of preventing a refusal to deal.

\footnotetext{
${ }^{23}$ See, for example, Olympia Equipment Leasing Co. v. Western Union Telegraph Co. 797 F 2d 370 (7th Cir. 1986) ("A monopolist has ... no duty to extend a helping hand to new entrants.") 376.

${ }^{24}$ See Ronald H.Coase, "The Nature of the Firm," Economica 4:386-405 (1937).
} 
The treatment of refusals to deal effected through other devices such as a contract using non-linear pricing, product design, and contractual tie-ins is more complicated than explicit refusals to deal under the antitrust laws. Following the logic just described, to preserve efficiencies which exceed deadweight losses, ties achieved through product design should be generally allowed (since it is directly analogous to vertical integration) while exclusivity achieved through contract ties (or through non-linear pricing or other terms) should be subject to scrutiny (though recall the caveats in dealing with non-linear pricing or other terms discussed in Case 2) because the courts have often interfered with such marketplace transactions on the implicit assumption that doing so does not give rise to large transaction costs.

Aside from cost reductions, the U.S. consumer has benefitted enormously from the introduction of new products. The introduction of new products has been responsible for the high standard of living enjoyed in the U.S. It is easy to see why. If the demand curve for a new product is $D$, then the entire area between the demand curve and marginal cost curve is a gain to society. Even the introduction of a product subject to monopoly power can represent a gain to society. That is the underlying logic of our patent system in which the monopoly profit expected from innovation creates an incentive to provide the gain to society. It has been estimated that the social return to invention significantly exceeds the private return. ${ }^{25}$ That means that, to promote invention, antitrust should be especially wary when its action reduces the return to innovators of intellectual property because we know that there already is too little incentive to create such intellectual property.

One of the ways firms protect intellectual property is to prevent it from falling in the hands of a competitor. One standard rationale for exclusive dealing is that it allows one manufacturer to give to its distributor customer lists without having to worry about the distributor using the information to sell another manufacturer's product. The same rationale could explain

\footnotetext{
${ }^{25}$ Charles I. Jones, and John C. Williams, "Measuring the Social Return to R\&D," 113 Quarterly Journal of
} 
why a Firm 1 with market power in A may refuse to deal with Firm 2 who sells complementary product B if Firm 2 may also become a competitor (or deal with a competitor) in product A. So, for example, suppose that Firm 1 makes computer chips, while Firms 2 and 3 purchase Firm 1's computer chips as inputs to make other products. In order to sell its chips, Firm 1 must explain their engineering properties to the user. Suppose Firm 2 now decides to develop its own chip business. Firm 1 refuses to deal with Firm 2 but continues to deal with Firm 3 . Attacks on this conduct and imposition of a duty for Firm 1 to deal on non-discriminatory terms with Firm 2 will weaken property rights in intellectual property, diminish the incentive to invest in computer chips, and widen the already existing gap between the social and private rate of return to innovation. ${ }^{26}$ This example highlights that it is not correct to characterize different terms of trade between Firms 2 and 3 as discriminatory because Firms 2 and 3 are not similarly situated. However, if no protection of intellectual property is involved, then the only distinguishing feature of Firms 2 and 3 is that Firm 2 intends to compete with Firm 1. In that case, an antitrust attack on Firm 1's discriminatory policy may make sense using one of the theories presented earlier because the only reason for the discrimination is 2's ability to erode monopoly profits by competing in computer chips. ${ }^{27}{ }^{28}$ Although there is a property right to protect intellectual property, there is no such property right to protect monopoly profits. ${ }^{29}$

(...continued) Economics, 1119-1135 (1998).

${ }^{26}$ Should there be any limit then on allowable behavior to protect intellectual property in light of this gap? Yes, assuming the goal is to prevent harm to competition. One should not, for example, allow behavior that destroys resources (e.g., bombing a rival's assets). I also would not allow cartels to form among rivals in order to raise the rate of return. The danger is that cartels will form for pretextural reasons just to raise rates of return regardless of whether intellectual property is involved. Also, if the firm has shown by its past behavior that it could contractually protect its intellectual property without resorting to a refusal to deal, then a defense of a refusal to deal based on protection of intellectual property should be required to explain why previous arrangements are no longer adequate. However, for reasons explained below, I would require the plaintiff to show a significant likely harm to competition.

${ }^{27}$ Proving that this fact pattern exists could be very difficult and fraught with error. This suggests that one should be wary of pursuing an antitrust claim under these circumstances.

${ }^{28}$ A practical problem arises if no Firm 3 exists. Then, forcing Firm 1 to deal with Firm 2 requires setting a price with no readily available benchmarks. An antitrust remedy would leave the antitrust authority in 
In summary, exclusionary conduct should not be attacked as creating a harm to competition absent a coherent theory explaining some mechanism of harm. That means that, in the absence of some sort of significant scale effects, there is unlikely to be a basis for attack based on the theories we have reviewed. But, even where theory suggests the possibility of competitive harm, the difficulty in identifying such harm and in distinguishing a harm to competition from a harm to competitors suggests caution. At a minimum, in order to avoid condemning efficient conduct, a plaintiff should be required to show a significant harm to competition and should not be allowed to prove only no efficiencies from the exclusionary conduct. Efficiencies are hard to measure and the benefit of the doubt should go to defendants not plaintiffs, unless one is prepared to jeopardize the continued generation of the large efficiency benefits responsible for raising our standard of living. Finally, certain non-contractual behavior -- e.g., vertical integration, physical tie-ins -- would seem to be beyond the reach of the antitrust laws under normal circumstances on the grounds that interfering in activities within a firm can entail large efficiency costs.

(...continued)

the unhappy position of having to set price. Notice that these circumstances would, based on the earlier discussion of non-intervention within a firm, generally favor non-intervention. Such a policy unfortunately creates a disincentive for firms to transact with others for fear of creating a benchmark that other firms who wish to deal can point to.

${ }^{29}$ There is a subtle point here. If Firm 1 is a monopolist of $A$, but competes with Firm 2 in the sale of a complementary product $B$, then, from our earlier analysis (Case $3 a$ ), Firm 1 can squeeze all profits from $B$ and that should not be a violation of any antitrust law if the goal is to prevent a harm to competition. However, if Firm 2 also competes with Firm 1 in Product C, an attempt to harm Firm 2's ability to compete in $\mathrm{C}$ could violate the antitrust law. Hence, if there were, for example, an economy of scope between B and C, theoretically Firm 1's refusal to deal (sell) in Product A with Firm 2 could harm competition in $C$. A price for $A$ that is so high as to drive Firm 2 out of $B$ would then be an action that harms competition in C. If Firm 2 is the only firm that Firm 1 deals with, then it would likely be an empirical nightmare to decide whether the high price for A to Firm 2 was to extract legitimate monopoly profits (as in Case $3 a$ ) or to destroy competition for $\mathrm{C}$. On the other hand, if there are firms that Firm 1 sells to that don't compete for A, and if they pay a different price than Firm 2, such a discriminatory policy could be subject to antitrust scrutiny, though I would urge great caution to make sure that those other firms provide a reasonable benchmark for Firm 2. See note 27. 


\section{REFUSALS TO DEAL -- LEADING CASES}

I now want to use the economic framework to analyze some of the leading refusal to deal cases. Two leading cases, Aspen and Kodak, stand out as leading cases for the proposition that a single firm has a duty to deal with its rival if that firm has market power. As we will soon see, those cases do not fall into any of our identified models where economic analysis suggests that refusals to deal harm competition. Hence, these two cases can be viewed as plaintiffs successfully taking property from defendants. These two cases represent dangerous precedents if they are broadly applied. I will then briefly discuss two cases that represent, in terms of our framework, sensible applications of antitrust in refusal to deal cases. Those cases are Lorain Journal and Microsoft.

\section{A. ASPEN $^{30}$}

Aspen Ski (Ski) owned three of the four mountains in Aspen. Aspen Highlands (Highlands) owned the fourth. The two firms competed with each other for skiers. The firms also collaborated by offering a day pass and a multi-day pass that allowed skiers to ski on any of Aspen's four mountains. The revenue from this collaborative effort was split pro rata in accordance with the results of a survey on how many skiers purchasing the four-mountain ticket skied on each firm's mountains. (Highlands got about $15 \%$ of the revenue from the collaborative effort from 1973 - 1976.) After several years of collaboration, Ski demanded a higher share of the revenue. Highlands refused and the collaboration ceased. In subsequent competition, Highlands' share eventually fell to $11 \%$ while Ski's rose. Highlands sought a variety of ways to itself make it easy for consumers to buy a four-mountain ski ticket, but Ski refused to cooperate. Highlands sued and won before the Supreme Court. The Court ruled that Ski had

\footnotetext{
${ }^{30}$ For insightful analyses of Aspen (Aspen Skiing Co. v. Aspen Highlands Skiing Corp. 472 U.S. 585), see Phillip E Areeda and Hovenkamp, Antitrust Law. (1999); Frank Easterbrook, "On Identifying Exclusionary Conduct," Notre Dame Law Review, 61: 972 (1986); and Jonathan Baker,. "Promoting Innovation Competition Through the Aspen/Kodak Rule," 7 George Mason Law Review 495 (1999).
} 
failed to present an efficiency justification for changing a collaboration that had produced a popular product, and therefore had violated the antitrust laws.

There are several troubling features about the economic logic underlying the notion that Aspen requires a firm to continue cooperation with a rival absent a business justification. The Court treated Aspen exactly as falling into my Case 1. (We will soon see that this is not entirely correct.) If the joint venture produced a superior product than either company could separately produce, then there is an incentive for the product to be produced. The only question is how the participants will share the profits. But a dispute about contract terms is a private dispute with no antitrust consequence. That Ski and Highlands each want more is understandable but beside the point. Moreover, Highlands would be willing to participate as long as it obtains more by participating in the joint venture than not participating. Highlands' decision not to take less is the unreasonable one -- unless it felt, as turned out to be correct, that it could use the Court to obtain better terms. But note this. In the absence of Court intervention, there is an incentive for the efficient bargain to be struck. There is no reason to regard the sharing of the joint venture profits as having anything to do with antitrust (again regarding this as Case 1). Indeed, the bargaining position of each would be affected by their "threat" point -- the outcome in the absence of agreement. In fact, we know that the share prevailing in the absence of the joint venture was $11 \%$ for Highlands -- which is lower than what it would have received in the joint venture deal that it refused.

The Court's position is simple. The consumers liked the four-mountain pass and it had been sold before on certain terms. Hence, according to the Court, they knew that the joint venture was feasible and beneficial. Such logic is, I think, partially correct but inapplicable here. That is, the Court is wary to impose an antitrust duty to deal where it might be imposing high costs by forcing firms to deal or by inventing price terms in a new setting. But previous behavior (or behavior toward others) can be used to show that those costs are not high. Although correct, such an approach penalizes change and therefore can make firms reluctant to enter 
such agreements initially. But, even if there is logic to the Court's reasoning, it is inapplicable here for the reason already stated: There is no antitrust gain from intervention. Absent intervention, the joint venture agreement would remain in force if it were efficient to do so -- just on worse terms for Highlands. According to the Court's logic, Highlands' refusal to accept the lowered price terms could be regarded as the antitrust violation! In short, it is hard to see any economic basis to use the antitrust laws to compel the joint venture to continue. The Court's holding in Aspen simply lacks economic logic. It's best use would be a very narrow reading that effectively removes it as a precedent for future cases. ${ }^{31}$

There is, however, one aspect that the Court pays little attention to that is at least a theoretically valid antitrust concern in light of our earlier analysis of refusal to deal. Absent the joint venture, the Aspen case falls into Case 2. Suppose Ski could somehow impose exclusivity on skiers -- i.e., you can't ski at any of Ski's three mountains if you ski also at Highlands. If there were significant scale economies, this could prevent Highlands from being an effective competitor. Now, Ski did not impose an exclusivity requirement, but did use a non-linear pricing schedule (6-day pass costs less than 6 times single day pass). Did this schedule create effective exclusivity that harmed competition? I don't know but at least it is perhaps a sensible question to investigate under a rule of reason. Are there scale economies? Were there enough single-day skiers so that critical volume was available? Were the price terms so unreasonable (recall the caveat in Case 2 on treating non-linear pricing as an antitrust violation) to justify treating it as exclusivity? Even if Highlands is harmed, are there offsetting efficiencies that Ski could claim? Although this exclusivity concern could have been an interesting antitrust issue to decide, it was not one that the Court did debate.

31 Judge Posner questions "whether Aspen stands for any principle that goes beyond its unusual facts." 797 F. 2d 370, 379 (7th Cir., 1986). There is another aspect that is troubling about Aspen, though the Court pays no attention to it. If, as the Court was forced to assume, the four mountains constitute a relevant market, then the joint venture is a merger to monopoly. The necessary revenue sharing agreement of the joint venture would require price discussions and the joint venture would seem to raise thorny antitrust issues as in BMI. . This issue was the subject of an antitrust action by the 


\section{B. ISO v. KODAK}

The most recent Supreme Court case regarding a duty to deal involves Kodak. ${ }^{32}$ Since that case has been analyzed in several articles, ${ }^{33}$ I will be brief. Kodak services its own photocopiers and so do independent service organizations (ISO). In order for an ISO to service a Kodak machine, it needs repair parts that only Kodak supplies. Kodak changed its policy of supplying repair parts to ISOs who, in response, brought an antitrust action. The issue the Court decided was this: If Kodak had no market power at the time of the initial sale (because there are multiple suppliers of photocopiers which also require subsequent repair parts and service), can the ISOs proceed to trial? The Court decided that the case should proceed to trial because there could be evidence to show an antitrust harm to competition from the action. ${ }^{34}$ The Court believed that the class of locked-in Kodak consumers could theoretically be harmed by the alleged diminution in competition. This decision commits two errors.

The first error is the failure to recognize that ex ante competition protects consumers. Consider the case where Kodak has developed a reputation (a likely case) about behaving competitively in its aftermarket activities. In that case, consumers -- often sophisticated businesses -- are aware of repair costs at time of purchase and, unless Kodak is exiting the business (which no one claimed), ex ante competition completely protects consumers. But, even if Kodak did not have a reputation for behaving competitively in the aftermarket, to the extent there are overcharges in the aftermarket that generate supracompetitive profits, ex ante competition among Kodak and its rivals for the initial sale guarantees that such profits will be given back to consumers. Moreover, because of the ex ante competition, Kodak has an

(...continued)

Colorado Attorney General.

32 Eastman Kodak Co. v. Image Technical Service Inc., 504 US 451 (1992).

33 E.g., Carl Shapiro, "Aftermarkets and Consumer Welfare: Making Sense of Kodak," 63 Antitrust Law Journal 483 (1995); Borenstein, Mackie , Mason and Netz, "Antitrust Policy in Aftermarkets," 63 Antitrust Law Journal 655 (1995); Benjamin Klein, "Market Power in Antitrust: Economic Analysis after Kodak," 3 Supreme Court Economic Review 43-92 (1992), and Dennis Carlton and Michael Waldman, "Competition, Monopoly and Aftermarkets," draft, (2000). 
incentive to behave efficiently in how it organizes and integrates its aftermarket and sales market activity. ${ }^{35}$. To stress, as the Court does, that the aftermarket market deviates from perfect competition adds nothing to the analysis. Every market does. But, if the goal of antitrust is to maximize society's welfare, intervention under the antitrust laws should occur only when such intervention can improve the state of competition. With ex ante competition combined with reputations and sophisticated buyers, or simply with ex ante competition alone, the competition should provide enough protection so that the antitrust laws are likely to do only harm when they are used to intervene in a market. To say that each case must proceed to trial because of a theoretical possibility of showing harm would turn the antitrust laws into a potent weapon for pursuing specious claims.

But even if, in Kodak, the Court made an error for failing to dismiss the case for lack of market power, it compounded its error by failing to recognize that Kodak is in a purely vertical relationship with its ISOs. That is, after the initial sale, the Kodak case is Case 3a. In a purely vertical case, Kodak has the monopoly right to charge whatever price it feels like for its monopolized product (parts). By doing so, it cannot affect competition for the parts since, by assumption, there are no other competitors. The illusion that ISOs restrain Kodak is premised on the notion that Kodak is obliged to charge a low enough price to ISOs to let them compete. Where does such a duty arise? If the antitrust laws permit a monopolist to charge a price above cost, there can be no antitrust liability from Kodak's behavior. ${ }^{36} 37$

\section{(...continued)}

34 Kodak subsequently lost that trial. (cite)

${ }^{35}$ See Dennis W. Carlton and Michael Waldman, ibid., for an analysis that shows that aftermarket activity that appears to prevent competition can enhance efficiency.

${ }^{36}$ Some commentators have explained that Kodak's change of policy may have surprised customers already locked in. But this would be true even in the absence of ISO competition if Kodak had raised repair part prices. Using antitrust to pursue what is a breach of contract claim has no economic foundation. Competition is not involved. Other commentators have been concerned about the inducement to overservice a photocopier if Kodak charges the monopoly price for repair parts. Again, this is not a harm caused by a reduction in competition. It is instead a harm caused by allowing a monopolist (of parts) to charge a price above marginal cost -- conduct that the antitrust laws allow. Moreover, even a monopolist wants to avoid such inefficiencies. There is no reason to believe that 
Our analysis has shown that there is no antitrust injury to consumers in either Aspen or Kodak, but even assuming that there is so that antitrust liability exists, the Court's decisions regarding proof seem misguided. The Court's decision in these cases has been interpreted to mean that a refusal to deal by a firm with market power requires an efficiency defense independent of showing a likely competitive harm (see, e.g., Baker, Jonathan. "Promoting Innovation Competition Through the Aspen/Kodak Rule," 7 George Mason Law Review 495. [1999]). But, unless competition is likely to be harmed, requiring an efficiency defense to avoid antitrust liability would be unwise. It would, in the absence of antitrust injury, give plaintiffs a chance to win an antitrust case based on whether some judge or jury not expert in the industry can understand a practice that may be hard to explain. The notion that some economists have that they (or businesses) can readily explain to laymen the basis for any business practice does not square with my experience. Indeed, as the literature in economics shows, economists often take decades to understand certain business practices. ${ }^{38}$ Unless the industry facts are such that a refusal to deal has a likelihood of adversely affecting competition, there can only be error introduced by demanding that a defendant offer convincing reasons for its business practices.

\section{LORAIN JOURNAL AND MICROSOFT}

Although I do have a general skepticism about the antitrust validity of many refusal to deal claims, and have explained why it would be mistake for two recent Supreme Court cases to

(...continued) court's intervention could better avoid the inefficiency than could the monopolist. See Carlton and Waldman (2000), supra at 5, for further elaboration of this point.

${ }^{37}$ One might ask why Kodak engaged in its behavior. Carlton and Waldman (2000), supra at 31, explain why such behavior is likely to be an efficient way to control the interaction between initial sales and the aftermarket.

${ }^{38}$ See Ronald H. Coase, "Durability and Monopoly," Journal of Law and Economics 15:1143-49 (1972) (showing how common practices regarding durable goods, heretofore misunderstood, are efficient), Scott E. Masten and Edward Snyder. "United States v. United Shoe Machinery Corporation: On the Merits," Journal of Law and Economics 36:33-70 (1993) (showing how some of United Shoes's practices from 50 years ago can now be understood as efficiency enhancing) and Darius W. Gaskins, Jr., "Alcoa Revisited: The Welfare Implications of a Secondhand Market." Journal of Economic Theory 7:254-71 (1974) (showing about 50 years later how the court should have analyzed the 
be followed broadly, I did earlier indicate that there can be scope for antitrust enforcement in refusal to deal cases. But I think those cases to be rare. I want to briefly indicate two cases where the refusal to deal could have adversely affected competition and where antitrust scrutiny was justified.

In Lorain Journal, ${ }^{39}$ the owner of that newspaper, which was the major local advertising vehicle, responded to the entry of a local radio station by refusing to deal with any customer advertising on the radio. Most commentators treat the newspaper and radio as substitutes, and so apply reasoning akin to that of my Case 2. But initially, it is better to view the radio and newspaper as complements for some advertisers -- ways of reaching different demographic groups. Otherwise, a firm would lose little by being able to advertise on only the radio. But, over time, the radio does grow into a substitute for newspaper advertising. That means Case 4 is a better way of understanding Lorain Journal. The behavior -- which as far as I can tell was not based on any efficiency defense -- was designed to so limit the size of the radio station that it would not survive as a vigorous competitor later on. What is unclear to me is how important are the initial scale effects in determining how fast the radio station could grow over time (as more people owned radios), but assuming they are important, the case seems reasonably decided against Lorain.

Let me finally turn to two aspects of the recent Microsoft cases -- Microsoft's effective refusal to deal with OEMs that dealt with other operating systems or Netscape, and Microsoft's product tie of Windows with Internet Explorer. ${ }^{40}$ There is considerable evidence that economies of scale and installed base matter in the computer industry. I will assume, as the Court found, that Microsoft has market power in operating systems. Microsoft did not use explicit exclusive

(...continued) secondhand market in Alcoa [U.S. v. Aluminum Co. of Am. 148 F 2d 416 2d Cit. 1945]). ${ }^{39}$ Lorain Journal v. U.S., 342 U.S. 143 (1951).

${ }^{40}$ See, e.g., U.S. v. Microsoft 1995 WL 505 998, \#3 (D.D.C. Aug. 21, 1995) (henceforth, Microsoft I), and U.S. v. Microsoft, 87 F. Supp. 2d 30 (D.D.C. 2000) (henceforth, Microsoft). I have worked on aspects 
dealing, but achieved de facto exclusive dealing by structuring contracts so that the payment to Microsoft that a computer manufacturer made depended not on how many computers it shipped with Windows but rather on how many computers it shipped in total whether or not they had a Windows operating system. Such an extreme pricing system easily could create exclusivity in Windows operating systems since the marginal cost of Windows is zero for incremental units. If every large OEM needs to ship some computers with Windows, this policy could have the effect of foreclosing rival operating systems from obtaining efficient distribution. This strikes me as a sensible antitrust concern which can be evaluated under a rule of reason. In Microsoft I, the Department of Justice attacked just such a claim and, under a consent decree, Microsoft agreed to discontinue the practice. Similarly, in U.S. v. Microsoft, several of Microsoft's contracts with original equipment manufacturers and Internet service providers either required or created incentives for exclusivity in browsers and were condemned under Section $2{ }^{41}$ The theory would be a straightforward application of the reasoning in Case 2.

The Microsoft case also alleged an illegal tie between Windows and Internet Explorer. Again, the logic would be a straightforward application of Case 4 with the dynamic interdependence caused by the importance of an installed base of applications that work on Windows. Although the mechanism of harm is clear, I want to focus on the two different tie-in claims. The first was a contractual tie. If you buy Windows, you also buy Internet Explorer. That is a type of tie that can likely be broken without creating large costs. The reason is the usual one: the tie occurs "outside the firm's boundaries" so there is not the risk that undue damage is done. In contrast, the second tie-in claim involved the physical commingling of the

(...continued) of the Microsoft cases adverse to Microsoft. See also Carlton and Waldman (2000), supra at 5. ${ }^{41}$ Whether the antitrust harm that an effective refusal to deal or exclusive dealing causes is actionable under Sections I or II is a legal question which I do not discuss. In Microsoft, the court held that Microsoft did not violate Section I by its exclusive dealing and effective exclusive dealing contracts, but that the same conduct did violate Section II. U.S. v. Microsoft, 87 F. Supp. 2d 30 (D.D.C. 2000). 
code of Internet Explorer and Windows together. Interfering in that tie requires the judgment that going inside a firm to redesign a product will not impose high costs.

The precedent of interfering in product design undercuts the basic policy principle: beware of creating inefficiency by interfering with activity inside a firm and especially beware of interfering with technological progress. It would seem that that principle should be adhered to in all but the most unusual circumstances, so long as the goal of the antitrust laws is to prevent harm to competition. ${ }^{42}$

\section{CONCLUSION}

Refusals to deal and related practices should generally be honored, if the goal of antitrust is to achieve efficiency. Although there are some legitimate circumstances justifying a duty to deal in order to prevent a harm to competition, those circumstances are relatively rare and were not present in either Aspen or Kodak. The consequences of Aspen and Kodak will be detrimental to competition unless those cases are read so narrowly that they lose their precedential value.

New economic models have greatly aided the understanding of strategic behavior involving refusals to deal and related practices. These models often have ambiguous welfare predictions. Therefore, before condemning a practice, it is incumbent on the economist to adduce evidence to establish that there is indeed likely to be a significant harm to competition from the practice. Without such evidence, the expansion of antitrust into creating a duty to deal will wind up harming consumer welfare.

\footnotetext{
${ }^{42}$ And perhaps the Microsoft case is one of those unusual circumstances because of the unusually large amount of very revealing e-mail on the topic of the tie-in.
} 
Fig 1

\section{Price}

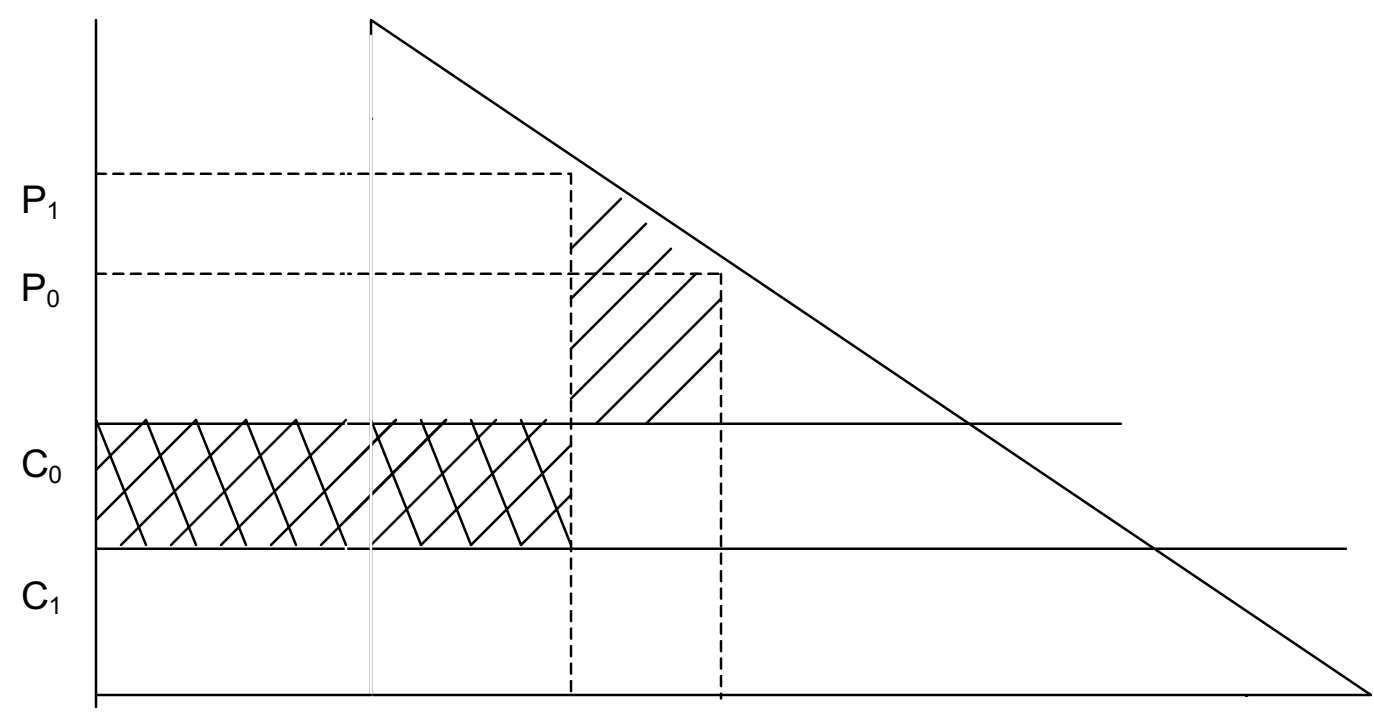

$q_{s}$

Quantity 